\title{
The Changing Pattern of Cardiovascular Risk Factors: the CroHort Study
}

\author{
Tamara Poljičanin ${ }^{1}$, Aleksandar Džakula ${ }^{2}$, Sanja Musić Milanovićé,3, Mario Šekerija ${ }^{3}$, \\ Davor Ivanković $\hat{c}^{2}$ and Silvije Vuletić ${ }^{2}$ \\ 1 Merkur University Hospital, Vuk Vrhovac University Clinic, Zagreb, Croatia \\ 2 University of Zagreb, School of Medicine, "Andrija Štampar« School of Public Health, Zagreb, Croatia \\ 3 Croatian National Institute of Public Health, Zagreb, Croatia
}

\begin{abstract}
A B S T R A C T
Croatia has a long tradition of non-communicable disease prevention, but also obstacles to the implementation of preventive programs related to the general attenuation of public health and primary health care sector. The aim of this study was to determine trends in behavioral and biomedical risk factors and evaluate primary non-communicable disease and cardiovascular prevention. Physical inactivity was a leading risk factor with increasing trend and prevalence of $33.9 \%$ and $38.9 \%$ in men and women in 2008. In 2008, obesity was present in $26.1 \%$ and $34.1 \%$, and hypertension in $65.8 \%$ and $59.7 \%$ of men and women. During the follow-up only smoking and alcohol consumption in men decreased significantly, while alcohol consumption and obesity in women, and hypertension in both sexes significantly increased. In the present situation, with the existing trends and environment it will not be possible to stop negative trends. Revitalization of public health activities and primary health care is essential.
\end{abstract}

Key words: CroHort study, prevention, non-communicable disease, cardiovascular disease, prevalence, trend

\section{Introduction}

Non-communicable diseases (NCDs) are a major public health problem. As lifelong diseases they lead to reduction in the quality of life and possibly to disability and premature death. At the same time they represent a growing burden to health economies. It has been estimated that $86 \%$ of deaths and $77 \%$ of disease burden in the European region is caused by this group of diseases mutually associated with common risk factors and opportunity for intervention. In the next decade the number of deaths attributable to NCDs will increase by $17 \%$ and health expenditures will continue to rise ${ }^{1}$. Poor countries will be worst affected and this will eventually lead to a further decrease in GDP, shortening of working life and life expectancy, and a reduced quality of life.

At the same time, NCDs are preventable and the majority of primary prevention strategies are aimed at modifying life style and individual risk factors in order to prevent disease. According to the World Health Organization (WHO), up to $80 \%$ of heart disease, stroke, and type 2 dia- betes and over a third of cancers could be prevented by eliminating shared risk factors, mainly tobacco use, unhealthy diet, physical inactivity and the harmful use of alcohol ${ }^{2}$. This integrated approach has already been proven in some successful public health interventions in the field of $\mathrm{NCDs}^{3-4}$. In order to promote investments in prevention and improved control of NCDs that may lead to improved quality of life, individual benefit and benefit to society, the regional WHO office for Europe adopted the European strategy for the prevention and control of non-communicable diseases »Gaining Health« in 2006 2 .

NCD, and especially cardiovascular disease prevention, has a long tradition in Croatia. Nevertheless, the obstacles to the implementation of preventive programs, recognized more than 20 years ago $^{5}$, have become even more pronounced in the post-transitional period.

The majority of problems associated with negative trends in prevention in the past 15 years can be related to the general attenuation of public health and primary 
health care sector, which are a consequence of an inappropriate model of decentralization and privatization ${ }^{6}$. Instead of clearly defining responsibilities for the prevention of cardiovascular diseases, legislation defined complex relations that significantly limit strategic management and efficient implementation of preventive programs. Examples are general practitioners and community nurses for whom neither a possibility nor an obligation to develop and improve relevant programs in the community have been anticipated, although that is their primary role ${ }^{7}$.

There is also the impact of free market economy and westernization in Croatia that seems to have an influence on cardiovascular risk factors and disease, but its extent and implications are still unclear.

In order to determine the consecutive trends in biomedical and behavioral risk factors and evaluate the results of primary NCD prevention in Croatia with particular concerns to cardiovascular disease, we analyzed the pattern of the existing NCD determinants in this study.

\section{Patients and Methods}

This study was a part of the Croatian Adult Health Cohort Study (CroHort), a repeated cross-sectional survey of adults aimed at providing a comprehensive community health assessment of Croats, including their access to and use of health care services, health status, and determinants of health such as nutrition, physical activity, smoking and alcohol consumption. The sample was first examined in the $2003 \mathrm{CAHS}_{\text {study }}{ }^{8}$ and re-examined in the 2008 Croatian Health Survey ${ }^{9}$. Namely, the 2008 Croatian Health Survey was a re-survey of the sample from CAHS 2003, and all the examinees who were examined in both 2003 and 2008 were considered as a single cohort of 3229 individuals. The most important behavioral risk factors as assessed in our study were defined as follows:

\section{Unhealthy diet}

Subjects who reported at least two of the following risks were considered as having an unhealthy diet: consumption of animal fat, milk and milk products with more than $3.2 \%$ of fat, eating cured meat every day or almost every day, not eating fruit every day, always adding salt to food.

\section{Physical inactivity}

Subjects who reported at least three of the following risk factors were considered as physically inactive: working at home, travelling to work by public transport, or working within a 15-min walking or cycling distance, easy or very easy job (sedentary or walking), physical activity less than 30 min a day during leisure time less than twice a week, advice received from a health care professional within the past year to increase physical activity.

\section{Smoking}

Subjects who reported never smoking, smoking only occasionally, or every day for up to 5 years more than 10 years before the survey were not considered to be at risk, whereas those who smokedat the time of the surveyor reported regular smoking for at least 5 years in the previous 10 -yr-period were considered to be at risk.

\section{Alcohol consumption}

Male subjects who reported drinking $40 \mathrm{~g}$ of alcohol or four or more servings per day and female subjects who reported drinking $20 \mathrm{~g}$ or two or more servings per day were considered to be at risk. Those amounts were considered to be equivalent to either 3 beers, 4 glasses of »bevanda " or "gemist « (wine and water in the proportion 1:1), 2 glasses of wine or 3 spirits in men and to 1 beer, 2 glasses of »bevanda « or "gemist«, 1 glass of wine or 1 spirit in women, respectively.

\section{Obesity}

Subjects with body mass index (BMI) equal or greater than $30 \mathrm{~kg} / \mathrm{m}^{2}$ were considered obese. BMI was calculated as weight (in $\mathrm{kg}$ ) divided with squared height (in meters)

\section{Hypertension}

Subjects with systolic blood pressure equal to or greater than $140 \mathrm{mmHg}$ or diastolic blood pressure equal to or greater than $90 \mathrm{mmHg}$ or those who reported taking antihypertensive drugs were considered to have hypertension.

\section{Statistical methods}

All statistical analyses were performed using SAS (version 9.1.3). The analysis included calculations of the prevalence of risk factors, intermediary risks and risk behaviors with $95 \%$ confidence intervals (CI). The p-value was computed based on the $z$-value for the respective comparison: $|\mathrm{z}|=\sqrt{ }[(\mathrm{N} 1 * \mathrm{~N} 2) /(\mathrm{N} 1+\mathrm{N} 2)]^{*}|\mathrm{p} 1-\mathrm{p} 2| / \sqrt{ }(\mathrm{p} * \mathrm{q})$ where $\mathrm{p}=(\mathrm{p} 1 * \mathrm{~N} 1+\mathrm{p} 2 * \mathrm{~N} 2) /(\mathrm{N} 1+\mathrm{N} 2), \mathrm{q}=1-\mathrm{p}, \mathrm{N} 1$ and $\mathrm{N} 2$ are the sample sizes, and $\mathrm{p} 1$ and $\mathrm{p} 2$ are the observed proportions in the compared groups. Statistical significance was set at $\alpha=0.05$ in all analyses $(p<0.05$; two-tailed).

\section{Results}

A total of 3229 participants $(31.43 \%$ male and $68.57 \%$ female; age $55.45 \pm 15.51$ ) was included in the study.

Smoking as a risk was present in $28.9 \%$ of men and $20.1 \%$ of women in 2003 . The difference between the sexes was statistically significant at the beginning. During the follow-up period, the prevalence in men significantly decreased to $22.9 \%$, while that in women decreased only slightly to $19.4 \%$, making the difference according to the sex insignificant in 2008.

Alcohol consumption was more frequent in men than in women in 2003 (9.0\% vs. 3.1\%). While the prevalence 
in men significantly decreased to $5.2 \%$, in women it significantly increased to $5.6 \%$, rendering both sexes similarly affected.

Physical inactivity was present in $33.3 \%$ of men and $33.9 \%$ of women in 2003 , and, although observed, the increase in the prevalence was insignificant; $36.7 \%$ of men and $38.1 \%$ of women were inactive in 2008 . During the study the differences between the sexes were found to be insignificant.

In 2003 the prevalence of unhealthy diet was significantly higher in men than women $(18.4 \%$ vs. $12.4 \%)$. Until 2008 it decreased in both sexes to $16.7 \%$ and $9.9 \%$, re- spectively. In spite of the insignificant decrease, the difference between the sexes remained significant.

Obesity was present in $23.9 \%$ of men and $26.1 \%$ of women in 2003; while in men the prevalence increased insignificantly to $25.3 \%$, the increase in women was highly significant with $34.1 \%$ of women being obese.

The prevalence of hypertension increased significantly in both sexes. In 2003 there were $52.7 \%$ male and $45.0 \%$ female hypertensive persons and in 2008 the prevalence increased to $65.8 \%$ and $59.7 \%$, respectively.

Prevalence of behavioral and biomedical risk factors are presented in Figure 1.

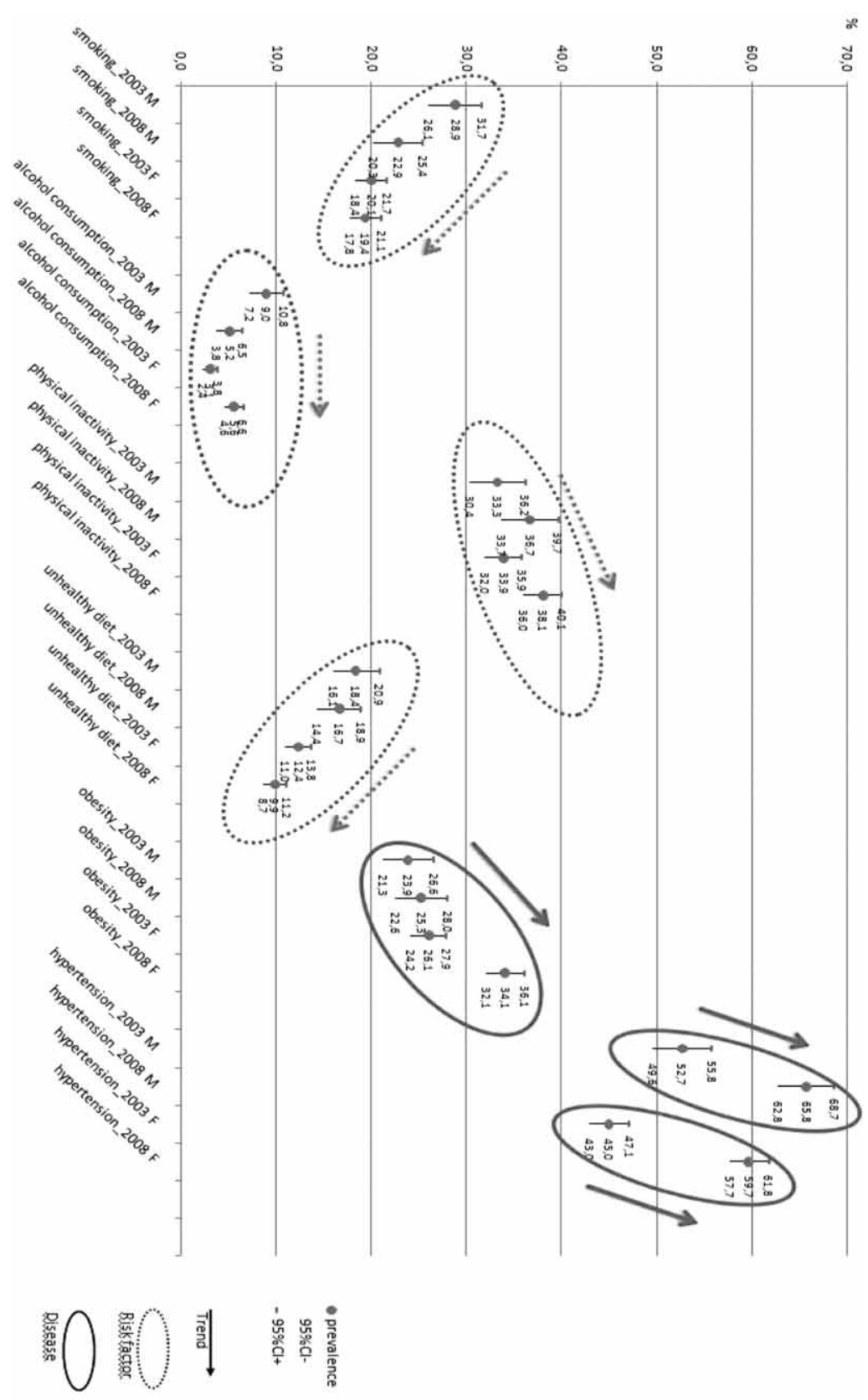

Fig. 1. Panoramic view on cardiovascular risk factors changes from 2003 to 2008. 


\section{Discussion and Conclusion}

Smoking and healthy diet were the only aspects in which the trend to better choices was present in both genders. However, the incidence of smoking decreased considerably only in men, whereas in women it decreased only slightly, making the difference between the sexes insignificant. According to the observed pattern, this can be assumed to be the third phase of the tobacco epidemic ${ }^{10}$ and a further decline in smoking prevalence in both genders and in smoking as a habit of the lower socio-economic groups can be expected.

Although previous studies have revealed changes towards better nutritional habits in almost one third of EU citizens ${ }^{11}$, our results confirmed only an insignificant decrease in either sex and a significantly lower prevalence of unhealthy diet in women.

In behavioral risk ranking physical inactivity was a leading risk factor with a prevalence of $33.9 \%$ and $38.9 \%$ in men and women in 2008. During the studied period an increase in the prevalence of physical inactivity was also observed, which can be partially explained by the relatively old age and aging of the participants.

The investigated biomedical risk factors were very frequent, obesity being present in $26.1 \%$ of the studied men and $34.1 \%$ of women, and hypertension in $65.8 \%$ of men and $59.7 \%$ of women in 2008. However, the high prevalence was not the worst problem, as during the follow-up period only smoking and alcohol consumption in men decreased significantly, while alcohol consumption and obesity in women, as well as hypertension in both sexes increased significantly. The increase in the prevalence of hypertension could be expected due to natural aging and related consequences, but the extent of those changes could be reduced in the future.

During the CroHort study some national activities related to primary cardiovascular and NCDs prevention tended to include several behavioral and biomedical determinants ${ }^{12}$ but primary prevention was mainly characterized by numerous regional and local, mono-sectoral interventions focused on a single specific disease lacking a modern integrated approach to shared risk factors ${ }^{2}$. However, during that period a multi-sectoral Action plan for the prevention of overweight and obesity was prepared and adopted by the government in $2010^{13}$.

At the beginning of 2004, the Ministry of Health and Social Welfare started a program of mandatory preventive exams by general practitioners in the population older than 50 years. The aim of that program was the early detection of cardiovascular diseases, hypertension, diabetes mellitus and anemia. During 2006 previously unknown cardiovascular disease was detected in $38.1 \%$ of the examined population and diabetes mellitus was diagnosed in $9.3 \%$ of examinees ${ }^{14}$. The rate of cumulatively examined citizens, however, was relatively low (16\%) with a decreasing trend in the number of citizens examined annualy ${ }^{15}$. Since 2004 registration of persons with diabetes to CroDiab registry has also become mandatory $^{16}$ and in 2007 the National Diabetes Program was announced ${ }^{17}$. In the field of early detection of cancers the National Program for the Early Detection of Breast Cancer was adopted in $2006^{18}$ and the National Program for the Early Detection of Colon Cancer in $2007^{19}$. With regard to smoking and its prevention, the most important was the Tobacco Law in 2008 completely prohibiting smoking in closed areas with minor exceptions ${ }^{20}$.

Despite all of the performed interventions, the trends revealed by this study are not satisfactory.

Westernization could be responsible for the present situation, being characterized by advanced work technology, sedentary leisure-time behavior ${ }^{21}$, and greater availability, lower cost and enhanced flavor of food that lead to energy imbalance, overweight, obesity and metabolic syndrome and related consequences. On the other hand, we all live in the obesogenic environment ${ }^{22}$. Many sedentary pursuits are available; fear that the outdoors in the cities is dangerous leads to less cycling, walking and running in childhood; eating pre-prepared meals containing excessive sugar and fats and spending leisure time in malls has become a new and modern lifestyle, whereas H\&M is a final step and proof that Croatia has encountered western Europe.

The present situation, with the trends and environment lacking explicit responsibilities for the NCDs prevention, strategic management provision and efficient implementation of preventive interventions, renders it impossible to stop these negative trends. Revitalization of public health activities and primary health care seems to be the only solution in this system approach and struggle with the challenges of the European Croatia.

\section{Acknowledgements}

The authors wish to thank all their colleagues from the extended CASH and CroHort teams and prof. L. Perkovic for editing this manuscript. This manuscript is prepared under the project of the Ministry of Science, Education and Sports, Grant No. 108-1080135-0264

\section{R E F E R E N C E S}

1. WHO, 2008-2013 Action Plan for the Global Strategy for the Prevention and Control of Noncommunicable Diseases, accessed 21.6.2011. Available from: URL: www.who.int/nmh/Actionplan-PC-NCDa2008.pdf -2 . WHO, Gaining health. The European strategy for the prevention and control of noncommunicable diseases. 2006, accessed 21.6.2011. Available from: URL: www.euro.who.int/Document/RC56/edoc08.pdf. 3. PUSKA P, Public Health Medicine 4(2002)5. - 4. Frieden TR, Bassett MT, Thorpe LE, Farley TA, Int J Epidemiol, 37 (2008) 966. — 5. HZJZ,

Izvješće o stanju i radu u zdravstvu Republike Hrvatske u 1990 godini, (HZJZ, Zagreb, 1991). - 6. Dzakula A, Sogorić S, Polasek O, Jurisa A, Andrić A, Radaković N, Todorović G, Coll Antropol, 33 (Suppl 1) (2009) 87. - 7. MAZZI B, Problem financiranja obiteljske zdravstvene zaštite $u$ Hrvatskoj. In: Proceedings (Sedmi kongres Hrvatskog društva obiteljskih doktora, Hrvatskog liječničkog zbora, Rovinj, 2007). - 8. VULETIĆ S, POLAŠEK O, KERN J, STRNAD M, BAKLAIĆ Ž, Coll Antropol 33 (Suppl 1) (2009) 3. - 9. IVIČEVIĆ-UHERNIK A, VULETIĆ S, KERN J, DEČKO- 
VIĆ-VUKRES V, MIHEL S, ERCEG M, PRISTAŠA I, Coll Antropol 36 (2012) suppl 1. 3. - 10. CAVELAARS AEMJ, KUNST AE, GEURTS JJM, CRIALESI R, GRÖTVEDT L, et al, BMJ, 320 (2000) 1102. - 11. EUROPEAN COMMISION, Health, food and alcohol and safety, 2003, accessed 21.6.2011. Available from: URL: http://ec.europa.eu/public opinion/archives/ ebs/ebs_186_en.pdf - 12. MZSS, Programi i projekti 2004-2007., accessed 21.6.2011. Available from: URL: http://www.mzss.hr/hr/content/download/ 2475/21542/file/MinZdravstvaProgramiProjekti20042007. pdf - 13. MZSS Akcijski plan za prevenciju i smanjenje prekomjerne tjelesne težine, accessed 21.6.2011. Available from: URL: http://www.mzss.hr/hr/ministarstvo/strategije i planovi/akcijski plan za prevenciju i smanjenje prekomjerne tjelesne tezine $2010 \_2012$ godine -14 . HZJZ, Preventivni pregledi osoba starijih od 50 godina, accessed 21.6.2011. Available from URL: http://www.hzjz.hr/publikacije/prevent_2007. pdf - 15. HZJZ, Croatian health service yearbook 2008, accessed 21.6.2011. Available from URL: http://www.hzjz.hr/publikacije/hzs_ljetopis/index.htm - 16. Poljičanin T, Pavlić-Renar I, Metelko Ž, Acta Med Croat, 59(2005) 185. — 17.
MZSS, Nacionalni program zdravstvene zaštite osoba sa šećernom bolešću s posebnim ciljem prevencije bolesti, accessed 21.6.2011. Available from: URL: http://www.mzss.hr/hr/programi_i_projekti/prevencija/nacionalni program zdravstvene zastite osoba sa secernom bolescu - 18. MZSS, Nacionalni program ranog otkrivanja raka dojke, accessed 21.6.2011. Available from: URL: http://www.mzss.hr/hr/programi_i_projekti/prevencija/nacionalni_program_ranog_otkrivanja_raka_dojke - 19. MZSS, Nacionalni program ranog otkrivanja raka debelog crijeva, accessed 21.6.2011. Available from: URL: http://www.mzss.hr/hr/programi_i_projekti/prevencija/nacionalni_program_ranog_otkrivanja_raka_debelog_crijeva - 20 . Zakon o ograničavanju uporabe duhanskih proizvoda (NN br.125/08), accessed 21.6. 2011. Available from: URL: http://narodne-novine.nn $\mathrm{hr} / \mathrm{clan}$ ci/sluzbeni/2008_10_125_3560.html - 21. HU FB, LI TY, COLDITZ GA, WILLETT WC, MANSON JE, JAMA, 289 (2003) 1785. - 22. Swinburn B, Egger G, BMJ, 329(2004) 736.

\section{T. Poljičanin}

Merkur University Hospital, Zajčeva 19, 10000 Zagreb, Croatia

e-mail:Tamara.Poljicanin@idb.hr

\section{PROMJENE KARDIOVASKULARNINH RIZIKA 2003-2008.; HRVATSKA KOHORTNA STUDIJA KARDIOVASKULARNIH RIZIKA (CroHort)}

\section{S A Ž E T A K}

Prevencija kroničnih nezaraznih bolesti u RH ima dugu tradiciju, no prisutne su prepreke u njihovoj implementaciji povezane sa slabljenjem javnozdravstvenog sektora i primarne zdravstvene zaštite kao posljedice neodgovarajuće decentralizacije i modela privatizacije. Cilj ovog ispitivanja bio je utvrditi trendove biomedicinskih i bihevioralnih rizičnih čimbenika te evaluirati primarnu prevenciju kroničnih nezaraznih i kardiovaskularnih bolesti analizirajući promjene učestalosti njihovih odrednica. Pušenje i zdrava prehrana bili su jedina obilježja s pozitivnim zdravstvenim trendom u oba spola, iako se statistički značajnim pokazalo jedino pušenje u muškaraca. Rezultati su potvrdili neznatno smanjenje učestalosti nezdrave prehrane u oba spola i značajno nižu prevalenciju u žena. Tjelesna neaktivnost je vodeći rizični čimbenik s prevalencijom od 33,9\% kod muškaraca i 38,9\% kod žena u 2008. god. i prisutim trendom porasta. Debljina je na kraju ispitivanja bila prisutna u $26,1 \%$ muškaraca i $34,1 \%$ žena, a hipertenzija u $65,8 \%$ muškaraca i $59,7 \%$ žena. Tijekom praćenja su značajno smanjene jedino prevalencija pušenja i konzumacije alkohola u muškaraca, dok su prevalencije konzumacije alkohola i debljine u žena i hipertenzije u oba spola značajno porasle. U sadašnjoj situaciji, uz prisutne trendove i okruženje te bez jasnog definiranja odgovornosti za prevenciju nezaraznih bolesti, strateškog upravljanja i učinkovite implementacije preventivnih programa neće biti moguće zaustaviti prisutne negativne trendove. Revitalizacija javnozdravstvenih aktivnosti i primarne zdravstvene zaštite je stoga neizostavna. 